\title{
ADVICE TO ASSERT THE PRIVILEGE AGAINST SELF-INCRIMINATION: CRIME OR CONSTITUTIONAL MANDATE?
}

The Ninth Circuit ruled recently in Cole v. United States ${ }^{1}$ that giving advice to claim the privilege against self-incrimination in a federal proceeding can be a criminal act punishable under Section 1503 of Title 18 of the United States Code, which reads, "Whoever corruptly, or by threats or force ...., endeavors to influence, intimidate, or impede any witness . . . in the discharge of his duty ... or corruptly, or by threats or force ... . influences, obstructs, or impedes, or endeavors to influence, obstruct, or impede the due administration of justice, shall be fined ... or imprisoned ...."2 The Cole decision raises important issues regarding advice to claim the privilege against self-incrimination since the general thought prior to Cole was that all advice to assert the privilege was lawful. ${ }^{3}$

In 1962 a federal grand jury conunenced investigating Cole for possible perjury in a prior grand jury investigation. Benton, a former employee of Cole, stated to the United States Attorney that his testinony in the current proceedings would conflict with Cole's answers in the prior grand jury hearing. According to prior arrangement with Cole, Benton inforned Cole of his decision to testify. In ensuing meetings Cole insisted that Benton invoke his privilege against self-incrimination. Benton was reluctant, but Cole continued to insist and threatened to expose Benton, who had previously submitted a false affidavit in another investigation. Benton's attorney at first advised hin against invoking the privilege against self-incrimination, but later acceded to Cole's demands. Benton appeared before the grand jury but did not testify, claiming his privilege against self-incrimination. Cole paid Benton's legal expenses. Later Benton voluntarily contacted the United States Attorney's office seeking protection for his family and himself. Under government instructions, Benton informed Cole that he had been subpoenaed again and did not want to claim the privilege against self-

1329 F.2d (9th Cir. 1964), cert. denied, 377 U.S. 954 (1964).

2 The various portions of $\S 1503$ of interest to this discussion are the following: (1) Corruptly endeavoring to influence, intimidate, or impede a witness; (2) endeavoring by threats or force to influence, intimidate, or impede a witness; (3) influencing, obstructing or impeding the due administration of justice by threats or force; (4) endeavoring to influence, obstruct or impede the due administration of justice by threats or force; (5) corruptly influencing, obstructing or impeding the due administration of justice; (6) corruptly endeavoring to influence, obstruct, or impede the due administration of justice.

3 United States v. Herron, 28 F.2d 122 (N.D. Cal. 1928). See Record, pp. 745-46, United States v. Grunewald, 353 U.S. 391 (1957); Brief for Appellant, pp. 26-28, Cole v. United States, 329 F.2d 437 (9th Cir. 1964). 
incrimination because of his job. Cole threatened Benton with loss of his job if he testified and added that Cole would insure that Benton kept his job if he invoked his constitutional privilege. Later Cole warned Benton that his family might be in danger if Benton testified. Cole was indicted, charged with corruptly, and by threats, endeavoring to influence a witness and to obstruct the administration of justice, and found guilty.

On appeal the court went beyond affirming the district court's decision, which adequately rested on threatening a witness, and discussed the issue of mere advice. The court agreed with the defense that section 1503 contains an implicit limitation on its literal language. In other words the statute does not proscribe acts consistent with the due administration of justice such as advising a witness to tell the truth. The privilege against self-imcrimination is an important and integral part of the due administration of justice, the court continued, and when a witness claims his privilege, he does not obstruct the administration of justice or do anything contrary to his duties as a witness. Advising a witness to assert his privilege against self-incrimination, however, is unlawful if the advice is given with a corrupt motive, for it is criminal to induce the innocent act for a corrupt purpose. Although the inducing cause is immaterial when the witness asserts his privilege against self-incrimmation, the motive of the inducer is important. Therefore, the witness is relieved from criminal hability, but the inducer is not since the privilege is the personal right of the witness, not to be utilized by another.

Section 1503 covers a wide range of conduct, but it is questionable whether advice to assert the privilege against self-incrimination, regardless of purpose, should be declared criminal under the statute. In Cole the defendant argued that a witness lias an absolute right to claim the privilege and does not commit an unlawful act by claiming it; therefore, to advise a witness to assert it was not a crime. This argument needs elaboration. First, it must be determined if in fact the privilege is absolute and whether its assertion by a witness is always a lawful act. If these propositions are established, it is still necessary to test the conclusion that advice to assert the privilege is not criminal by examining the arguments upon which this conclusion might rest. This test involves statutory interpretation, application of criminal law, and recognition of constitutional requirements. This Comment will undertake to conduct such a test. ${ }^{4}$

${ }^{4}$ Two cases at first appear relevant to the issue under discussion. The government contended in Cole that Grunewald v. United States, 233 F.2d 556, 559, 571 (2d Cir. 1956), rev'd on other grounds, 353 U.S. 391 (1957), squarely supported the proposition that advising a witness to claim the privilege against self-incrimination was a crime under $\S 1503$, Brief for Appellee, p. 33, Cole v. United States, 329 F.2d 437 (9th Cir. 1964). Grunewald, however, 
THE RIGHT OF A WITNESS TO CLAIM THE PRIVILEGE AGAINST SELF-INCRIMINATION

The right of a witness to refuse to testify by asserting his privilege against self-incrimination as provided in the fifth aunendment has been much discussed and will not be reviewed in detail. ${ }^{5} \mathrm{~A}$ determination of the extent the privilege is available to a witness is necessary, however, as groundwork for an analysis of the statute.

The privilege applies to any testimony which will provide a hink of information in the chain of evidence which might tend to incriminate the individual. ${ }^{6}$ The nature of the privilege prevents effective challenge or inquiry into the reasons why the witness claims it. ${ }^{7}$ In the main, law enforcement agencies are required to do their work without the assistance of the accused, the suspected, and the witnesses who miglit be implicated ${ }^{8}$ this notion is in accord with the principle estabhishing a fair balance between the state and the individual and requiring the state to shoulder the entire burden in its contest with an individual. ${ }^{9}$

held that one may not advise a witness to testify falsely or to withhold the truth. The trial judge in Grutrewald instructed the jury that if they could conclude that the defendant urged a witness not to tell the truth, they could find the defendant guilty, but that the defendant was to be acquitted if they concluded that the ouly advice given was to retain an attorney or to invoke the constitutional privilege against self-incrimination, Record, pp. 745-46, United States v. Grunewald, 353 U.S. 391 (1957). The jury found the defendant guilty. The issue involved was that of advising a witness to testify falsely, as indicated by the opinion of the court of appeals. Grunewald v. United States, 233 F.2d 556, 559, 571 (2d Cir. 1956).

The defense in Cole claimed United States v. Herron, 28 F.2d 122 (N.D. Cal. 1928), a federal district court case, should guide the court's decision. Brief for Appellant, p. 41 . The defendant was charged with conspiring to obstruct the administration of justice by influenc- . ing a witness to claim the privilege against self-incrimination, thus raising the pure issue of advice. The court sustained the defendant's demurrer to the indictment. The result is correct, but the court failed to adequately enunciate its underlying basis. The court went directly from the assumption that a witness had an absolute right to claim the privilege, motive being immaterial, to its conclusion that to advise a witness to claim it was not a crime. In so doing, the court hurdled the difficult questions of the application of the literal language of the statute to the acts and motives of the advisor, and of the constitutional problems arising if the act were declared criminal. The court's conclusion cannot stand unless these obstacles are first recognized and discussed.

5 See generally Grisword, The Fifte Amendment Today (1955); 8 Wrgarore, EviDENCE $\$ \S 2250-84$ (3d ed. 1940); Fortas, The Fifth Amendment, 25 CuEve. B.A.J. 92 (1954); Morgan, The Privilege Against Self-Incrimination, 34 MnNN. L. Rev. 1 (1949); Pittman, The Colonial and Constitutional History of the Privilege Against Self-Incrimination, 21 VA. L. REV. 763 (1935).

6 Hoffman v. United States, 341 U.S. 479, 486-87 (1951).

7 See ibid; Fortas, supra note 5 , at 100.

8 United States v. Gordon, 236 F.2d 916, 919-20 (2d Cir. 1956) (dictum).

9 See Murphy v. Waterfront Commission, 378 U.S. 52 (1964) for the pobicies behind the privilege against self-incrimination; Fortas, supra note 5 , at 97-98. 
Therefore, the individual does not have to furnish information to aid the government if that information might tend to incriminate him.

The courts have struggled with the dilemma of giving full adherence to the principle of the privilege against self-incrimination, and yet of reconciling it to the principle which condemns the suppression of evidence, hindering the effort of the law to establish the truth. ${ }^{10}$ Caught in this dilemma, the courts have attempted to qualify the privilege. For example, the Supreme Court stated that the privilege could be used solely for the benefit of the witness, not a third party, ${ }^{11}$ and that it should be confined to cases where a witness had reasonable grounds to fear incrimination $;^{12}$ the mere possibility of incrimination was not sufficient. If a witness refused to testify after failing to qualify for the privilege, he could be cited for contempt. ${ }^{13}$ Finally, in Hoffman $v$. United States, ${ }^{14}$ the Court formulated the current test. A witness must have reasonable cause to apprehend danger and cannot exonerate himself from testifying merely because he declares that he will incrimmate himself. The trial court is to determine whether his silence is justified and is to require his testimony if it clearly appears that the witness is mistaken. Taken alone, such language makes it evident that the privilege is not absolute. Doubt, however, is cast upon this principle by other language in Hoffman and later decisions applying the Hoffman test.

In Hoffman, after declaring that the trial court was to determine the validity of the claim, the Court added that a witness need not prove the danger of incrimination in the sense usually required, since such proof would force a surrender of the information which the privilege is desigued to protect. Thus, it need only be evident from the implications of the question in the context asked that an answer or explanation why it cannot be answered night be injurious. The privilege is to be given hiberal construction, notwithstanding the burden on diligent and efficient law enforcement, since any other conclusion would seriously compromise an important constitutional liberty. Hoffman, on one hand, seems to place a substantial qualification on the privilege; yet, on the other hand, the decision makes an even stronger argument for its unhampered exercise.

Further doubt is cast on the Hoffman language qualifying the privilege

10 See Mason v. United States, 244 U.S. 362, 364 (1917); Malloy v. Hogan, 378 U.S. 1, 34 (1964) (White, J., dissenting); 2 So. CaL. L. Rev. 394 (1929).

11 Hale v. Henkel, 201 U.S. 43, 69-70 (1906).

12 Mason v. United States, 244 U.S. 362, 365 (1917).

13 E.g., Rogers v. United States, 340 U.S. 367 (1951); Mason v. United States, 244 U.S. 362 (1917).

14341 U.S. 479 (1951). 
by the application of Hoffman to later cases. In United States $v$. Trock ${ }^{15}$ a witness was charged with contempt after refusing to answer the following questions: Whether he had operated a business in New York, had offices at a certain address, had stayed at a certain hotel, had registered in any trade in New York, and could type. The trial court stated that the evidence failed to show that the answers to the questions asked would link the witness with any criminal activity and held he was not privileged to refuse to answer on the ground of self-incrimination. The court of appeals upheld the trial court's power to determine whether the witness was justified in refusing to answer the questions. Citing Hoffman, the Supreme Court reversed without cominent. The liberal interpretation given Hoffman was seen agam in the recent case of Malloy $v$. Hogan. ${ }^{16}$ The defendant had been convicted in 1959 of a gambling misdemeanor and had served a suspended sentence. Sixteen months later he refused to disclose the names of his associates in the 1959 incident. He was sentenced for contempt, the Connecticut Supreme Court ruling that the fifth amendment did not apply to the states and that there was insufficient possibility of incrimination to justify his assertion of the state constitutional privilege. The Supreme Court reversed, stating that the privilege under the fifth amendment did apply to the states and that the federal standard as enunciated in Hoffman permitted the defendant to successfully assert the privilege. The Hoffman language qualifying the privilege thus is but a paper qualification which in practice does not impair it. ${ }^{17}$ The Court will protect the privilege rather than risk impairment by allowing any significant discretion to the lower courts in determining whether it can be exercised..$^{18}$

15232 F.2d 839 (2d Cir. 1956), rev'd per curiam, 351 U.S. 976 (1956).

16378 U.S. 1 (1964).

${ }^{17}$ See the suggestion in Mr. Justice White's dissent that the Supreme Court is adhering in form to the federal standard of incrimination, while eroding the standard by its application. $1 d$. at 38 .

18 In In re Atterbury, 316 F.2d 106 (6th Cir. 1963), the witness refused to answer any questions asked him, claiming his privilege against self-incrimination. The district court disallowed the claim, but the court of appeals reversed because of the liberality of the ruling in Hoffman and its application in later cases, Simpson v. United States, 241 F.2d 222 (9th Cir. 1957); Wollam v. United States, 244 F.2d 212 (9th Cir. 1957); MacKenzie v. United States, 244 F.2d 712 (9th Cir. 1957), all three cases rev'd per curiam, Sinipson v. United States, 355 U.S. 7 (1957); Emspak v. United States, 349 U.S. 190 (1955); Quinn v. United States, 349 U.S. 155 (1955); United States v. Singleton, 193 F.2d 464 (3d Cir. 1952), rev'd per curiam, 343 U.S. 944 (1952); United States v. Greenberg, 192 F.2d 201 (3d Cir. 1952), rev'd per curiam, 343 U.S. 918 (1952), in which judgments of conviction for refusing to answer apparently innocuous questions were reversed by the Supreme Court because of the possibility that an answer might link a witness with criminal activity.

In Shendal v. United States, 312 F.2d 564 (9th Cir. 1963), a court of appeals reversed 
Where there is an absence of incriminatory implications arising from the questions and context in which they are asked, the burden is on the witness to prove the validity of the claim. ${ }^{19}$ From a practical view the incriminatory implications will be present in all but the rare case. ${ }^{20}$ If these implications are present, a witness has an absolute privilege, and the court cannot probe into his motives. ${ }^{21}$ In effect the court has no choice but to allow the assertion of the privilege. The inability of the court to search into the motives of a witness has been questioned; ${ }^{22}$ yet, it is apparent that to inquire into the witness's motives without his acquiescence would be to undermine his privilege. Since a witness has little difficulty qualifying to clain the privilege, he in effect commits no unlawful act. ${ }^{23}$ In addition the exercise of the privilege against selfincrimination is considered an integral part of the adnninistration of

a contempt conviction where a witness refused to continue answering questions. The court admitted there was a strong possibility that the witness was protecting a third party but interpreted Hofman to the effect that the claim of the privilege was valid unless a court could find that any prospective answer could not possibly incriminate or form a link in the chain of evidence.

${ }^{10}$ Even this rule is questionable in light of Simpson v. United States, 241 F.2d 222 (9th Cir. 1957), rev'd per curiam, 355 U.S. 7 (1957), where a witness refused to give his place of residence, claiming, without supporting reasons, the privilege against self-incrimination. In affirming the contempt conviction, the court of appeals had stated, "but certainly in the unusual case some burden is on the defendant or his counsel to suggest . . . how facts ordinarily not incriminating might reasonably tend to be incriminating in their special setting." 241 F.2d at 224.

20 See text accompanying notes $15-18$ supra and cases cited in note 18 supra. It would be extremely difficult to show that a witness is clearly wrong if he offers no reasons why he claims the privilege. The courts have in effect established that the possibility of incrimination is present when certain types of questions are asked, Note, 78 HaRv. L. REv. 223, 226 (1964). Mr. Justice White has declared that the Supreme Court "has all but stated that a witness's invocation of the privilege is to be automatically, and without more, accepted." Malloy v. Hogan, 378 U.S. 1 (1964) (White, J., dissenting).

A different situation exists when a witness offers specific reasons why he elaims the privilege. In these cases the court can and does judge the merits of the claim in light of the reasons advanced by a witness, and if it determines the witness is clearly wrong, he can be adjudged in contempt for failing to testify. See, e.g., Rogers v. United States, 340 U.S. 367 (1951).

21 See Ex parte Irvine, 74 Fed. 954, 960 (C.C.D. Ohio 1896).

22 See United States v. Courtney, 236 F.2d 921, 924 (2d Cir. 1956) (Lumbard, J., dissenting); however, even Judge Lumbard admits that the courts must rely on the witness's claim to an extent since forcing him to divulge his reasons may defeat a valid claim of the privilege. He wonld allow the courts to inquire into the motives of a witness if the clain of the privilege were a mere afterthought. $I d$. at 926 .

23 The assumption is that in the usual case the incriminatory implications will be present. In determining whether a witness should be adjudged in contempt for refusing to testify after asserting his privilege against self-incrimination, the test is not whether a witness in truth has a valid claim of possible incrimination but whether the incriminatory implications are deemed present. If these implications are present, as they will be in almost every case, the true unotives of a witness for claiming the privilege are immaterial. 
justice ${ }^{24}$ and, therefore, does not adversely influence, hinder, or obstruct it.

II

\section{ADVICE AND THE CORRUPT INTENT}

The defense strongly asserted in Cole that, since a witness has an absolute right to exercise the privilege against self-incrimination, no crime is committed by advising a witness to claim it. In testing this assertion, it is necessary first to look at the statute. Examination of section 1503 reveals that while the act is not specifically proscribed, it is covered by the statute's broad scope.

Section 1503 is one of a series of statutes under the heading Obstructing of Justice. ${ }^{25}$ Its progenitor was Section 2 of the Act of March 2, $1831 ;^{26}$ this Act represented a congressional effort to curtail the range of conduct which federal courts could punish as contempt. ${ }^{27}$ The original language of section 2 has not been materially altered. Under common law principles, obstructing the due administration of justice was likened to obstructing an officer in serving process, ${ }^{28}$ but there is a distinction today between obstructing justice, which goes back to the Enghish crime of obstructing service of process and arrest, ${ }^{29}$ and obstructing the due administration of justice, which involves interference with the determination by any legally constituted agency of the rights of persons and property. ${ }^{30}$

Section 1503 defines several distinct ways in which the crime of obstructing justice may be committed. ${ }^{31}$ It specifically prohibits various acts such as corruptly endeavoring to influence a witness in the discharge of his duty, and it also contains an omnibus clause proscribing any endeavor, whether corruptly or by threats or force, to influence, obstruct, or hinder the due administration of justice. The omnibus clause apparently was added by the framers in order to cover acts that they

24 Cole v. United States, 329 F.2d 437, 439 (9th Cir. 1964).

2518 U.S.C. $\S 1501$ (assault on process server); $\S 1502$ (resistance to extradition agent); § 1503 (influencing or injuring officer, witness, or juror generally); $\$ 1504$ (influencing juror by writing); $\S 1505$ (influencing or injuring witness before agencies and committees); § 1506 (theft or alteration of record or process; false bail); $\S 1507$ (picketing or parading).

26 Section 2, Act of March 2, 1831, 4 Stat. 487.

27 In re Michael, 326 U.S. 224, 227 (1945). For an interesting summary of the events leading to the adoption of the Act of March 2, see Nelles and King, Contempt by Publication in the United States, 28 CoLUM. L. REv. 401, 423-31 (1928).

28 United States v. Seeley, 27 Fed. Cas. 1010, 1013 (No. 16248a) (C.C.S.D.N.Y. 1844).

${ }^{29}$ See 4 Blacrstone, Comanentaries *129; United States v. Seeley, supra note 28 , at 1013.

30 See Rosner v. United States, 10 F.2d 675, 676 (2d Cir. 1926).

31 See United States v. Meltzer, 100 F.2d 739, 741 (7th Cir. 1938). 
were unable at that time to foresee. ${ }^{32}$ The statute is broad enough to cover any act, committed corruptly, in an endeavor to imfluence a witness in the discharge of his duty or to influence, obstruct, or hinder the administration of justice, ${ }^{33}$ but it is not unconstitutional because of vagueness. $^{34}$

Some of the essential elements of the crime-endeavor, witness, administration of justice, and corrupt - have received broad interpretation. Endeavor is related to attempt but avoids the evidentiary problems arising if the word attempt is used. The word endeavor allows a court to reach into the preparation stage, ${ }^{35}$ whereas the word atteinpt does not cover inere preparation. ${ }^{36}$ The endeavor, not the success, is declared to be the crinie; success merely aggravates the endeavor. ${ }^{37}$

The situation of mere advice to a witness to exercise his privilege against self-incrimination in order to protect the advisor can come under either clause. A person need not be subpoenaed in order to be considered a witness under the statute. It is sufficient that the defendant know that the person approached intends to testify ${ }^{38}$ The due administration of justice has been defined as the performance of acts or duties required by law in the discharge of a duty. ${ }^{39} \mathrm{~A}$ witness's duty is to testify truthfully. There can be no argument that an advisor has not inet the essential elements of endeavoring to influence a witness or of endeavoring to influence, obstruct, or inpede the due administration of justice; therefore, the defense must rest on the argument that the endeavor is not corrupt.

Corrupt has been defined as any endeavor to influence a witness or to impede or obstruct the due administration of justice. ${ }^{40}$ This definition is not satisfactory, for corrupt loses its meaning as an element of the crinie. It assunies a criminal intent froin the physical acts of the defendant. This definition would eliminate the mens rea requirement as

32 United States v. Bonanno, 177 F. Supp. 106, 114 (S.D.N.Y. 1959), rev'd on other grounds sub nom., United States v. Bufalino, 285 F.2d 408 (2d Cir. 1960).

33 Broadbent v. United States, 149 F.2d 580, 581 (10th Cir. 1938).

34 Anderson v. United States, 215 F.2d 84, 90 (6th Cir.), cert. denied, Lewis v. United States, 348 U.S. 888 (1954).

35 United States v. Russell, 255 U.S. 138, 143 (1921).

36 At comnion law acts remotely leading towards the commission of the offense were not considered criminal attempts, whereas acts inmediately connected with it were. Regina v. Eagleton, Dears 515, 538, 169 Eng. Rep. 826, 835 (1855).

${ }^{37}$ See, e.g., Knight v. United States, 310 F.2d 305, 307 (5th Cir. 1962); United States v. Solow, 138 F. Supp. 812 (S.D.N.Y. 1956).

38 United States v. Grunewald, 233 F.2d 556, 571 (2d Cir. 1956).

39 Rosner v. United States, 10 F.2d 675, 676 (1926).

40 See, e.g., Broadbent v. United States, 149 F.2d 580, 581 (10th Cir. 1945); Bosselman v. United States, 239 Fed. 82, 86 (2d Cir. 1917); United States v. Cohen, 202 F. Supp. 587, 588-89 (D. Conn. 1962). 
has been done in other areas. ${ }^{41}$ This could not have been the intent of Congress, however, because obstruction of justice was considered a common law offense, ${ }^{42}$ and because Congress clearly specified that the endeavor must be corrupt. ${ }^{43}$ The mens rea requirement, therefore, must be met; there must be a specific intent to influence a witness to do something inconsistent with his duty or a specific intent to do some act or acts which adversely affect the administration of justice. ${ }^{44}$ If that specific intent is missing, the act is not corrupt, an essential element of the crime is not met, and the defendant cannot be convicted.

Corrupt is thus a state of mind which accompanies the physical act. Two distinct arguments can be made by the defendant that the corrupt intent is missing when he endeavors to influence a witness to assert his privilege against self-incrimination in order to protect the advisor. The first would interpret the word corrupt as having an implicit limitation that it does not include an intent to influence a witness to do an act which if successful would be consistent with the duty of the witness and with the due administration of justice. Such a determination has been made in the case of advising a witness to tell the truth. ${ }^{45}$ Telling the truth is in no way inconsistent with a witness's duty nor does it in any

41 See, e.g., United States v. Balint, 258 U.S. 250 (1922) (defendants claimed indictment failed to charge knowledge that drugs were regulated by statute when sold by them; Supreme Court ruled that the Narcotics Act did not make knowledge an element of the offense) and United States v. Dotterweich, 320 U.S. 277 (1943) (Supreme Court upleeld statute making it a misdemeanor to introduce adulterated or misbranded drugs into interstate commerce; Court stated such legislation dispensed with the conventional requirement of awareness of wrongdoing).

42 See Morissette v. United States, 342 U.S. 246 (1952) in which the Supreme Court makes it clear that when Congress omits intent as an element of a crime, the Court will presume a congressional purpose to do away with the mens rea requirement only when public welfare statutes are involved; the Court will not presume an intent by Congress to eliminate the mens rea requirement when the crime is considered a common law offense. Id. at 250-63.

43 In cases where the mens rea requirement was abandoned, the statutes in question did not specify intent as a necessary element of the crime. Section 1503, however, specifies that the intent that accompames the act must be corrupt.

44 See Knight v. United States, 310 F.2d 305, 307 (5th Cir. 1962); Cole v. United States, 329 F.2d 437, 439-41 (9th Cir. 1964).

45 Harrington v. United States, 267 Fed. 97, 101 (8th Cir. 1920). It might be argued that bribing a witness to tell the truth would be a crime. See The Queen v. Darby, 7 Mod. 100, 101, 87 Eng. Rep. 1121, 1122 (1702) (dictum). In State v. Ventola, 122 Conn. 635, 191 Atl. 726 (1937) the court indicated that a defendant does not liave to bribe a witness to testify falsely in order that the defendant be convicted; it is sufficient that a witness testify more favorably than lie otherwise would. Therefore, bribery, the same as threatening or larming a witness, is the act which the law seeks to prohibit; there is no need to look at what the defendant seeks to accomplish by the bribe. The intent to bribe is sufficient. In the case of endeavoring to influence a witness in the discharge of his duty, lowever, a court must look at what the defendant seeks to achieve in order to determine if the accomplished act is inconsistent with the duty of a witness. If a court cannot look 
manner adversely affect the due administration of justice. Similarly, a court might conclude that advice to assert the privilege against self-incrimination was not accompanied by a corrupt intent since a witness does nothing inconsistent with his duty when he exercises his privilege and since the administration of justice is not adversely affected because the assertion of the privilege by a witness is contemplated as an integral part of the administration of justice. This argument should not prevail, however, because the privilege against self-incrimination is to be used solely for the benefit of a witness. ${ }^{46}$ True, the motives of a witness are immaterial if the incriminatory implications are present as they will be in most cases. This protection, however, does not extend to third persons. Notwithstanding the leeway allowed a witness in qualifying to claim the privilege against self-incrimination, a witness does in fact perform an act inconsistent with his duty when he exercises the privilege to protect a third party. Also, the due administration of justice entails performance of acts required by law in the discharge of a duty. The law requires a witness to testify unless he might be incriminated by his testimony; then he may invoke his privilege against self-incrimination. The administration of justice does not contemplate the exercise of the privilege for the benefit of a third party, and therefore the administration is adversely affected when the privilege is exercised to protect a third party, even though the present judicial standard gives a witness wide latitude in invoking the privilege.

The second argument would be that the act of advising a witness to assert his privilege against self-incrimination is not corrupt because the doctrine of legal impossibility abrogates criminal intent. The argument is based on the proposition that section 1503 , by the use of the word endeavor, is written in terms of attempt; ; $^{47}$ consequently, section 1503 must be analyzed from the structure of the law of attempt. Criminal attempt encompasses a wide expanse of human conduct but is not without himitations. One limitation is the proximity and equivocality requirements $;^{48}$ another is impossibility.

beyond the endeavor to influence, it can never find out if the corrupt intent made necessary by the statute is present.

46 Mason v. United States, 244 U.S. 362, 365 (1917).

47 An attempt is an endeavor to do an act carried beyond mere preparation, Allen v. State, 22 Ala. App. 74, 75, 112 So. 177,178 (1928), and is an endeavor to do a certain act which falls short of execution, People v. Cosad, 1 N.Y.S.2d 132, 134, 253 App. Div. 104, 105 (1937). It is apparent that the words "attempt" and "endeavor" are closely related. See 1 BISHOP, Crmmmai LAW \$§ 435, 724 (8th ed. 1892).

48 In order to ensure that persons are not punished for mere thoughts the law has formulated a test of proximity which goes to the physical act. This test requires tbe individual to be close enough to success to be considcred sufficiently dangerous to warrant sanctioning. This test, however, does not resolve the problem of proving criminal intent. Thus, the equivocality test requires that the act on its face show the criminal intent. If 
At one time a person could not be convicted of attempt unless the act attempted was possible, but the modern view is that an act done with intent to commit a crime, even though it is impossible to commit it in the manner attempted, is a criminal attempt. ${ }^{49}$ To attempt to commit an act, however, which is legally impossible to commit because the consummation of the act is not unlawful is not a criminal attempt. ${ }^{50}$ Factual (physical) impossibility is demonstrated by a pickpocket attempting to pick an empty pocket. An example of legal impossibility is the case of Lady EIdon ${ }^{51}$ attempting to avoid paying duty tax by smuggling French lace into England. Unknown to Lady Eldon the tax had been repealed. Nevertheless, she proceeded with her plan thinking she was attempting a crime. In this situation the consummated act could not result in a crime because there was no law against importing French lace without paying a duty tax. It was legally impossible to commit the crime; so the attempt to complete the act likewise could not be criminal because the criminal intent was not present..$^{52}$ An intent to commit a supposedly wrongful act might be present, but it could not be a violation of the criminal law. "Ignorance of the criminal law camiot be a factor in rendering non-criminal conduct crimmal anymore than it can be a factor in rendering criminal conduct non-criminal." ${ }^{\prime 53}$ The distinction between physical and legal impossibility is recognized and applied in attempt $t^{54}$ and conspiracy ${ }^{55}$ cases.

a true equivocality test is applied, proximity to success is not important so long as the intent is manifested by the act. Also, under this test an individual could be on the verge of success (close enough to warrant conviction under the proximity test) and yet escape conviction if the act on its face did not show a criminal intent. See Campbell v. Ward, [1955] N.Z.L.R. 471; Model Penac Code \& 5.01(2) (Proposed Official Draft, 1962). The latter attempts to merge the two tests by requiring a substantial step which is strongly corroborative of the actor's criminal intent.

40 Stephen, Crmmatid Law 52 (7th ed. 1926).

50 "If what a man contemplates doing would not in law be a crime, he cannot be said, in point of law, to intend to commit the crime. If he thinks his act will be a crime, this is mere mistake of his understanding, where the law holds it not to be such. His real intent being to do a particular thing, if the thing is not a crime, he does not intend to commit a crime, whatever he may erroneously suppose." 1 Bishop, Cramtnal Law $\$ 742$ (7th ed. 1882). For discussions of attempt and impossibility, see generally PAULSEN AND Kadish, Crantwal Law and Its Processes 467-86 (1962); Sayre, Criminal Attempts, 41 HaRv. L. Rev. 821 (1928); Smith, Two Problems in Criminal Attempts, 70 HaRv. L. Rev. 422 (1957); Strathorn, Effects of Impossibility in Criminal Attempts, 78 U. PA. L. REv. 962 (1930).

51 Lady Eldon is the principal in another hypothetical suggested in 1 WHARToN, CrIMrNAL LaW 304 n.9 (12th ed. 1932).

52 See Paulsen and Kadist, op. cit. supra note 50, at 484-85.

63 Ibid.

54 E.g., People v. Teal, 196 N.Y. 372, 89 N.E. 1086 (1909); People v. Jaffe, 185 N.Y. 497, 78 N.E. 169 (1906).

55 E.g., Ventimigha v. United States, 242 F.2d 620 (4th Cir. 1957); O'Kelley v. United States, 116 F.2d 966 (8th Cir. 1941). 
If the doctrine of legal impossibility applies to the case of advising a witness to assert his privilege against self-incrimination, the intent to commit a criminal act is not present, and the defendant must be acquitted since the corrupt imtent is missing.

A series of hypotheticals demonstrates that the defense of legal impossibility should not be allowed. Assume $A$ will be incriminated by $B$ 's testimony as a witness. $A$ attempts to kill $B$ by shooting at $B$ 's bed in the dark but fails because $B$ decided to sleep in the adjacent bed. Applying the accepted standards of attempt, $A$ can be convicted of attempted murder and of endeavoring to obstruct the administration of justice under the omnibus clause of section 1503. A's defense of impossibility does not relieve him of criminal liability since his situation involves plyysical impossibility.

Assume $A$ mistakenly thought $B$ had been subpoenaed as a witness, and $A$ attempted to kill $B$ in the manner described above. $A$ can be convicted of attempted murder but cannot be convicted of endeavoring to obstruct the admimistration of justice because $B$ was not a witness. There might be confusion whether this would present a problem of legal impossibility or a failure to meet the statutory requirements. In other words, an essential eleinent of the crime was missing since $B$ was not a witness. The better view would acquit $A$ on the charge of endeavoring to obstruct the administration of justice since one of the essential elements of the crime liad not been met, ${ }^{56}$ although an argument could be made to acquit because of legal inpossibility. ${ }^{57}$

Now assume $B$ 's testimony might incriminate $A . B$ will not in fact incriminate himself by his testimony, but the theoretical incriminatory implications arising from the questions easily will qualify him to claim the privilege against self-incrimination. In order to protect himself, $A$ advises $B$ to claim his privilege. Has $A$ committed a crime under section 1503 or should he be acquitted because of the application of the doctrine of legal impossibility? $A$ claims that successfully influencing a witness to assert his privilege against self-incrimination is not inconsistent with the witness's duty and does not hinder the due admimistration of justice; therefore, it is legally impossible to commit a crime under section 1503. There are three reasons why this defense should fail: (1) It does not present a true legal impossibility situation; (2) it proposes an unnecessary extension of the doctrine of legal impossibility; and (3) an unlawful act does in fact result when a witness asserts his privilege to protect a third party.

The Lady Eldon hypothetical is a true legal impossibility case be-

56 PAULSEN AND KadiSH, op. cit. supra note 50, at 484 n.z.

57 See text accompanying notes 58-60 infra. 
cause there is no law prohibiting the ultimate act. Advising a witness to claim his privilege against self-incrimination, however, is not a true legal impossibility situation because there does exist a law, section 1503, which prohibits what the defendant is trying to achieve. The defendant wants to protect limself by preventing the witness's testimony; this certainly is prohibited by section 1503. If a defendant endeavors to accomplish his objective by advising a witness to stay away from the proceedings, he can be convicted. In the case of advising a witness to exercise the privilege against self-incrimination, however, the defendant's endeavor to achieve his objective takes on a veneer of legality because the endeavor apparently consummates in a lawful act when a witness exercises his privilege. This situation thus gives the appearance of being one in which an essential element is not inet in that the exercise of the privilege supposedly would be consistent with a witness's duty and the due administration of justice. The courts do not always apply a true legal impossibility test and sometimes allow, under the heading of legal impossibility, cases which in reality are ones of factual impossibility ${ }^{58}$ or in which an essential element of the crime is not met, ${ }^{59}$ leaving the door open for the argument that advice to assert the privilege against selfincrimination should be classified a legal impossibility case. This area of the law is unsettled, making difficult the drawing of clear lines between these categories. ${ }^{60}$ It is recommended that a court not add to the confusion and that it disallow the defense. Only a true legal impossibility defense should be allowed.

It is important to distinguish between the act of the defendant and of the witness. The defense of legal impossibility apphies where a defendant's consummated act cannot result in an unlawful act. In the case of successfully advising a witness to exercise his privilege agamst selfincrimination, the lawful act is said to be the exercise of the privilege by a witness. The defense of legal impossibility would depend upon a lawful act by a third person. The availability of the defense of legal impossibility should depend on whether the consummated act of the defendant is lawful not whether the witness's consummated act is lawful. ${ }^{01}$

58 E.g., State v. Guffey, 262 S.W.2d 152 (Mo. App. 1953) (defendant shot a stuffed deer believing it to be alive).

69 E.g., Ventimiglia v. United States, 242 F.2d 620 (4th Cir. 1957) (defendant charged with conspiring to pay off an employee representative, but court determined person to whom money was to be paid was not an employee representative).

$60 I d$. at 626 .

61 But cf. People v. Teal, 196 N.Y. 372, 89 N.E. 1086 (1909), in which defendant's conviction of an attempt at subornation of perjury was reversed because the person actually giving the false testimony at trial could not have been guilty of perjury; therefore the de- 
Assuming a court would be willing to determine the applicability of the doctrine by the legality of the acts of the witness, the requirements of the legal impossibility doctrine still should not be satisfied because in our lyypothetical the witness's conduct is unlawful. Although the present judicial standard allows a witness almost complete discretion whether he wishes to assert his privilege, the privilege is not absolute, and it is unlawful if the privilege is exercised to protect a third person.

\section{III}

\section{ADVICE AND THE CONSTITUTIONAL IAW}

Although a defendant advising a witness to assert his privilege against self-incrimination should be convicted since lis act is encompassed within the terms of section 1503, constitutional limitations dictate that conviction slould fail. In effect the privilege of a witness is absolute; yet it can be lost if a witness waives it. The problem arises when a witness responds to an incriminating question because he is unaware of the availability of the privilege. If he had been adequately advised, he could have avoided waiver. Here a conflict exists, for it inust be determined whether advice concerning the constitutional privilege is necessary for the proper exercise and preservation of the privilege against self-incrimination, or whether the principle condemning the suppression of evidence overrides the privilege at this point.

The right of a witness to receive advice froin an attorney and the duty of an attorney to give advice to his client are accepted principles of the judicial process. A witness should also be able to obtain information and advice froin other sources since "we liave ... learned the companion lesson of history that no system of criminal justice can, or should, survive if it comes to depend for its continued effectiveness on the citizens' abdication througl unawareness of their constitutional riglits." ${ }^{\prime 22}$ The individual must be advised of lis constitutional privileges in order to properly exercise them. For the individual to be properly informed, his information must be uncensored. ${ }^{63}$ It is proposed that the giving and receiving of advice is an indispensable part of the privilege against self-incrimination, for the privilege is of no value if the witness cannot properly exercise it because of lack of knowledge. If advice is denied the witness because the giving of advice is declared a crime, the privilege is inpaired to that extent.

fendant could not be convicted of subornation of perjury. Following through, the court determined that an unsuccessful attempt to do what would not have been a crime when effectuated, could not be held to be an attempt to commit the crime charged.

62 Escobedo v. Illinois, 378 U.S. 478, 490 (1964).

63 See Marsh v. Alabama, 326 U.S. 501, 508-09 (1946); Schwartz, The Mail Must Not

Go Through-Propaganda and Pornography, 11 U.C.L.A.L. REv. 805, 823-58 (1964). 
Two significant first amendment decisions indicate that where the defendant, in order to protect himself, advises a witness to assert the privilege against self-incrimination, a strong argument can be made that (1) a witness is deprived of his first amendment right to receive information; (2) the constitutional privilege against self-incrimination under the fifth amendment is impaired because advice is an integral part of the privilege; and (3) a defendant has standing to raise the constitutional issue. Recently in Zeitlin v. Arnebergh ${ }^{64}$ the Califorma Supreme Court allowed a prospective reader to raise the constitutional issue that prohibiting distribution of a book considered obscene would violate the reader's rights guaranteed by the first amendinent. In Marsh v. Ala$b a m a^{65}$ the Supreme Court decided that a state cannot impose criminal liability on a person distributing hiterature on a company town sidewalk since to do so would in essence curtail the right of each individual citizen to receive literature and thus deprive these people of the liberties guaranteed by the first amendment.

Section 1503 as applied in Cole hinders the constitutional privilege of the witness by declaring the giving of advice a crime and in essence depriving a witness of a potential source of information, raising a first amendment issue. If advice is an integral part of the privilege, declaring advice criminal impairs the privilege against self-incrimination, evoking a fifth amendment argument. No constitutional right of the advisor is hindered by declaring his act criminal; therefore, his defense must rest on an infringement of the constitutional riglit of a witness. Tlie standing problem is not as difficult as it first appears in liglit of Marsh v. Alabama, which allowed the defendant to raise the constitutional issue of the individual citizens of the company town. ${ }^{66}$ The present trend of the Supreme Court to carefully protect the constitutional privileges of the individual ${ }^{67}$ lends support to this constitutional challenge to the application of section 1503. If self-interested advisors are silenced by section 1503 , the witness might still receive advice to exercise his privilege from disinterested individuals, but silencing the former group makes it less likely that he will be informed as they liave the strongest nnotivation to inform him. Also a witness can seek the information if he desires it, but this assumes a witness has sufficient knowledge of the privilege to make a determination whether he should seek advice. ${ }^{68}$ In addition, if aid is sought and

0459 Cal. 2d 901, 905-07, 383 P.2d 152, 154-56, 31 Cal. Rptr. 800, 802-04 (1963), cert. denied, 375 U.S. 957 (1964).

65 Marsh v. Alabama, 326 U.S. 501, 507-09 (1946).

60 See Schwartz, supra note 63 , at $841-45$.

67 E.g., Escobedo v. Illinois, 378 U.S. 478 (1964); Malloy v. Hogan, 378 U.S. 1 (1964); Gideon v. Wainwright, 372 U.S. 335 (1963); Robinson v. California, 370 U.S. 660 (1962). 68 Cf. People v. Dorado, 62 A.C. 350, 364-65, 398 P.2d 361, 370-71, 42 Cal. Rptr. 
advice given with intent to protect the advisor and to influence the witness, the literal language of section 1503 would still make this act a crime. The language in Cole indicates that under section 1503 even the right of an attorney, priest, or spouse to give advice is not absolute. ${ }^{00}$ The privilege of the witness is impaired more clearly if advice from these accepted sources of information is restricted.

As previously indicated, Cole presents more than the pure issue of advice. There was sufficient evidence to convict the defendant of threatenmg a witness, and therefore there was no need to decide the pure issue of advice. In view of the Supreme Court's reluctance to impair the privilege against self-incrimination, as indicated by the line of cases following Hoffman, ${ }^{70}$ the proper resolution of this problem would be to allow a person to advise a witness to assert the privilege, regardless of the intent which accompanies the advice. Advice to assert the privilege should be considered an mtegral part of the privilege and thus an integral part of the administration of justice. To disregard the intent of the advisor does not throw open the door to justify any means to influence a witness to assert the privilege against self-mcrimination. There still remains the distinction betweęn a threat and advice. ${ }^{71}$ The distinction should be resolved by the trier of fact.

Rodolfo Montejano

169, 178-79 (1965) (dictum), petition for cert. filed, 33 U.S.L. WEEK 3323 (U.S. March 22, 1965) (No. 1012).

69329 F.2d 437, 440 (9th Cir. 1964) (dictum).

70 See notes 15-18 supra and accompanying text.

${ }^{71}$ See note 2 supra. 